\title{
Influence of orofacial pain, in superficial and deep tissue, on the anxiety levels in rats
}

\section{Influência da dor orofacial, em tecidos superficiais e profundos, no nível de ansiedade em ratos}

\begin{abstract}
Purpose: The present study aimed to determine the influence of orofacial pain in superficial and deep tissue on anxiety levels in male Wistar rats.

Methods: Orofacial pain was induced by injecting $50 \mu \mathrm{L}$ of $1 \%$ formalin in the lip (superficial tissue) and in the temporomandibular joint (TMJ) (deep tissue) of male Wistar rats. The anxiety level was measured by the elevated plus maze (EPM) test. The standard measures (number of entries into open and enclosed arms, and time spent in opened ones), were recorded. The three measures of plus-maze behavior calculated were the percentage of entries into the open arms (\%EOA) (100 X open/total), the percentage of time spent in the open arms (\%TSOA) (100X open/total) and the number of entries into the closed arms (NECA). Data were analyzed with ANOVA and Tukey's tests.

Results: The formalin injection in the lip and in the TMJ region significantly increased the anxiety level as measured by the percentage of time spent inside and the number of entries in the open arms of the EPM test, but did not increase the general activity measured by the number of entrances in the closed and opened arms. Anxiety response was significantly reduced by Diazepam ${ }^{\circledR}$ administration $(1 \mathrm{mg} / \mathrm{kg}$ ) before the formalin injection to lip/TMJ.

Conclusion: The results suggest that the orofacial nociceptive response induced by the injection of $1 \%$ formalin in the lip or TMJ region increases the anxiety level in rats and that Diazepam ${ }^{\circledR}$ can reduce it.
\end{abstract}

Key words: Orofacial pain; anxiety; rats; EPM

\section{Resumo}

Objetivo: Este estudo objetivou determinar a influência da dor orofacial, em tecidos superficiais e profundos, sobre o nível de ansiedade em ratos machos Wistar.

Metodologia: A dor orofacial foi induzida pela injeção de $50 \mu \mathrm{L}$ formalina a 1\%, na região de lábio (†ecido superficial) e da articulação temporomandibular (ATM) (†ecido profundo) de ratos machos Wistar. A ansiedade foi medida utilizando o teste do labirinto em cruz elevado (LCE).

Resultados: Os resultados demonstraram que as injeções de formalina no lábio e na ATM aumentaram significativamente o nível de ansiedade, medido pela porcentagem de tempo gasto nos braços abertos e pela porcentagem de entrada nos braços abertos do LCE, mas não aumentou a atividade geral medida pelo número de entradas nos braços abertos e fechados do LCE. A ansiedade foi significantemente reduzida pela administração de Diazepam ${ }^{\circledR}$ $(1 \mathrm{mg} / \mathrm{kg})$, previamente à injeção de formalina no lábio e na ATM.

Conclusão: Os resultados sugerem que a dor orofacial induzida pela injeção de formalina $1 \%$ na região do lábio e da ATM é capaz de aumentar o nível de ansiedade em ratos e que a administração de Diazepam ${ }^{\circledR}$ pode reduzir esta resposta.

Palavras-chave: Dor orofacial; ansiedade; rato; LCE

\author{
Daniela de Cassia F. Boleta-Ceranto ${ }^{a}$ \\ Fábio José Bianchi ${ }^{\mathrm{b}}$ \\ Cristina Sayuri Nishimura Miurac \\ Maria Cecília F. de Arruda Veiga ${ }^{d}$ \\ Laerte Luiz Bremm c
}

\begin{abstract}
a Department of Basic Sciences, Division of Physiology, Paranaense University, Cascavel, PR, Brazil

${ }^{b}$ Department of Basic Sciences, Division of Biochemistry, Paranaense University, Cascavel, PR, Brazil

cPeriodontology Department, Paranaense University, Cascavel, PR, Brazil

dDepartment of Basic Sciences, Division of Physiology - University of Campinas, Piracicaba, SP, Brazil
\end{abstract}

Correspondence:

Daniela de Cassia Faglioni Boleta-Ceranto

Rua Carlos Bartolomeu Canceli, 950 - sobrado 42

Cascavel, PR - Brasil

85.81 1-280

E-mail: dcboleta@unipar.br

Received: April 12, 2010

Accepted: October 21, 2010

Conflict of Interest Statement: The authors state that there are no financial and personal conflicts of interest that could have inappropriately influenced their work.

Copyright: (C) 2010 Boleta-Ceranto et al.; licensee EDIPUCRS. This is an Open Access article distributed under the terms of the Creative Commons AttributionNoncommercial-No Derivative Works 3.0 Unported License. 


\section{Introduction}

Previous studies have shown an association between psychological changes and temporomandibular joint dysfunction (TMD) $(1,2)$. It has been estimated that approximately $20 \%$ to $30 \%$ of the adult population will experience TMD in their lifetime (3), and pain associated with TMD may occur in about $70 \%$ of patients diagnosed with these disorders (4).

Pain is an unpleasant experience that reflects on interpersonal relationship. It is considered an aversive stimulus able to alter the patient's level of anxiety. Anxiety is an emotional state subjectively considered unpleasant or threatening, including symptoms such as alterations in the mood and cognition, mostly followed by behavioral and physiological changes, such as palpitation, and sudoresis (5). Anxiety can become pathological when a response to the stimulus becomes exaggerated and irritating interfering in the quality of life (5). Considering that thoughts and feelings related to pain suffering may play an important role in dental distress similarly to the pain in other parts of the body, anxiety is probably the most important of the non-sensory components of dental pain (2). In the last years different studies have analyzed the possible role of anxiety in pain responses (1), but the influence of pain, mainly orofacial pain, on anxiety levels is still unknown.

To measure pain and anxiety in human beings is very complex. Animal models may help to investigate the mechanisms involved in normal and pathological behavior. The formalin (FT) and the elevated plus-maze (EPM) tests are useful tools to study pain and anxiety, respectively.

The FT is widely used as a model for subacute tissue injuryinduced pain in rodents (6). The formalin injection into the paw elicits a biphasic behavioral response in rats $(7,8)$. This test is considered a model of inflammatory tonic pain and it is sensitive to many classes of analgesic drugs (9). An adaptation of this test for assessing pain and analgesia in the orofacial region of the rat was introduced by Clavelou et al. (1995) (10). The formalin injection in the upper lip induced a nociceptive behavioral response in the animal characterized by rubbing the formalin-injected upper lip whit the ipsilateral fore or hindpaw. In 2001, Roveroni et al. (11) developed a behavioral model of orofacial pain in deep tissues of rats using formalin injection in the TMJ region. The formalin administration in the TMJ causes behavioral responses in rats characterized by moving the mandible, rubbing the orofacial region and flinching the head quickly.

The elevated plus maze test is one of the most widely used models in animals, in contemporary preclinical research on anxiolytic drugs and neurobiological mechanisms of anxiety $(12,13)$. This model is based on the natural fear of open and elevated alleys (14). As a consequence, rats on the EPM tend to avoid the open arms and stay more on the enclosed arms. Anxiolytic drugs increase the number of entries and the time spent in the open arms, whereas anxiogenic agents does the opposite (15). When confined to the open arms, rats show behavioral and physiological manifestations of fear, such as freezing, defecation, and plasma corticosteroids increasing. Different aversive stimuli are able to alter the animal's anxiety level (12). Pain is also considered an aversive stimulus that generates many behavioral alterations.

Therefore, the present investigation explores the possibility of orofacial pain, in superficial (in lip) as well as in deep (in TMJ) tissues, to modify the anxiety level of rats and the administration of Diazepan ${ }^{\circledR}$ role in this process.

\section{Methods}

Wistar male rats, "specific pathogen free" (CEMIB, University of Campinas - UNICAMP, Piracicaba, SP, Brazil), 3-monthold, were used ( $\mathrm{n}=10-15$ per group). Groups of five animals were housed in plastic cages with food and water ad libitum, under constant conditions of temperature $\left(22 \pm 2^{\circ} \mathrm{C}\right)$, humidity and a 12:12 h light/dark cycle. The animals were not handled before starting the experiments. The experimental sessions were conducted between 7:30 and 11:30 AM. All procedures were approved by the Institutional Animal Care and Use Committee (Protocol 392-102).

The EPM test consisted of two open arms measuring 50 $\mathrm{X} 10 \mathrm{~cm}$, crossed at right angles with two opposed arms of the same size. The latter were enclosed by $40 \mathrm{~cm}$ high walls, except for the entrance. The four arms delimited a central area of $10 \mathrm{~cm}^{2}$ where the arms crossed. The whole apparatus was elevated $50 \mathrm{~cm}$ above the floor. To prevent the rats from falling down, a rim of Plexiglas ${ }^{\circledR}(1 \mathrm{~cm}$ high $)$ was made to surround the perimeter of the open arms. The experimental sessions were recorded by a vertically mounted video camera, linked to a monitor and a VCR in an adjacent room. Afterwards, the videotapes were analyzed by three calibrated observers who were blinded to the treatment conditions.

The solutions administered in the experiment were: Halothane $^{\circledR}$ (Cristália, São Paulo, SP, Brazil); Diazepam ${ }^{\circledR}$ (Roche, Jacarepaguá, RJ, Brazil) diluted in propilenoglicol $40 \%(01 \mathrm{mg} / \mathrm{kg})(16) ; 1.0 \%$ Formalin prepared from $37 \%$ stock formaldehyde (Sigma-F-1635, Sigma Chemical Co ${ }^{\circledR}$; St Louis, MO, USA) further diluted in $0.9 \%$ saline; Blue Evans 1\% (Sigma Chemical Co ${ }^{\circledR}$; St Louis, MO, USA) dissolved in physiological saline (30 $\mathrm{mg} / \mathrm{kg}$ body weight). On the experiment day, the animals were taken to the test laboratory room, at least 30 minutes before treatment, and anaesthetized with halothane for $40 \mathrm{~s}$ before any procedure. To evaluate the effect of superficial (lip) and deep (TMJ) orofacial pain on the anxiety level, the rats were randomly allocated to the experimental groups shown in Table 1.

Gentle aspiration ruled out any intravascular placement, after administration of $50 \mu \mathrm{L}$ of the experimental solution. For the lip and TMJ injection a 30-gauge needle was used associated with a 0.5 -in needle coupled to a Hamilton microsyringe through a polietylene canule. After the EPM test, the formalin/saline TMJ group received intracardiac injection of Evans' blue dye to confirm if the formalin administration was adequate. 
Table 1. Phase I of the experimental study: groups and treatments.

Table 2. Phase II of the experimental study: groups and treatments.

\begin{tabular}{ll}
\hline \multicolumn{1}{c}{ Groups } & \multicolumn{1}{c}{ Procedures } \\
\hline group 1 (anesthetic control) $(\mathrm{n}=15)$ & rats only anaesthetized by halothane \\
group 2 (formalin in the lip) $(\mathrm{n}=15)$ & $50 \mu \mathrm{L}$ formalin 1\% applied in the lip ${ }^{16}$ \\
group 3 (saline in the lip) $(\mathrm{n}=15)$ & $50 \mu \mathrm{L}$ saline applied in the lip ${ }^{16}$ \\
group 4 (formalin in the TMJ) $(\mathrm{n}=12)$ & $50 \mu \mathrm{L}$ formalin 1\% applied in periarticular area ${ }^{11}$ \\
group 5 (saline in the TMJ) $(\mathrm{n}=15)$ & $50 \mu \mathrm{L}$ saline applied in periarticular area ${ }^{11}$ \\
\hline
\end{tabular}

\begin{tabular}{ll}
\hline \multicolumn{1}{c}{ Groups } & \multicolumn{1}{c}{ Procedures } \\
\hline group $6(n=15)$ & $50 \mu \mathrm{L}$ formalin 1\% applied in the lip + diazepam \\
group $7(n=12)$ & $50 \mu \mathrm{L}$ formalin 1\% applied in the lip + vehicle \\
group $8(n=11)$ & $50 \mu \mathrm{L}$ formalin 1\% applied in TMJ region + diazepam \\
\hline
\end{tabular}

To validate the behavioral result and evaluate the $\gamma$ Aminobutyric acid (GABA) role in the alteration observed in experiment 1, other experiments were performed (Table 2).

Animals were anesthetized with halothane prior to intraperitoneal drug administration, $30 \mathrm{~min}$ before formalin/ vehicle injection in the lip or TMJ. After treatment, the rats were placed in an individual cage and taken to the behavioral room for a 30-min waiting period before the EPM-test. For the behavioral test each rat was placed in the central square facing an enclosed arm, and allowed to freely explore the EPM for $5 \mathrm{~min}$. The standard measures (number of entries into open and enclosed arms, and time spent in opened ones), were recorded. The three measures of plus-maze behavior calculated were the percentage of entries into the open arms (\%EOA) (100 X open/total), the percentage of time spent in the open arms (\%TSOA) (100 X open/total) and the number of entries into the closed arms (NECA) $(12,13)$.
Data were statistically analyzed by using ANOVA followed by Tukey's tests at the significance level of $5 \%$. The softwares used for statistical calculations were Minitab, Estat and Sisvar (Globaltehc, Santo Agostinho, BA, Brazil).

\section{Results}

For the effect of formalin injection in the lip and in the TMJ region groups on anxiety levels, local factors and treatment of anxiety and locomotor activity in animals submitted to the EPM test were significant, but with no interaction between these two factors. For local factor, no statistically significant difference was found between anxiety and locomotor activity when formalin was injected in the region of TMJ or lip $(P<0.05)$ (Table 3 and Fig. 1). Regarding the treatment factor, formalin $1 \%$ administration increased $(P<0.05)$ anxiety level significantly as assessed by the \%TSOA and the \%EOA (Table 3 and Fig. 1).

Table 3. Comparison of \%TSOA,

$\%$ EOA and NECA between control and experimental groups submitted to the EPM test after injection of saline or formalin in the lip or TMJ. Mean ( \pm standard error of the mean).

\begin{tabular}{lccccc}
\hline & $\begin{array}{c}\text { Control group } \\
(\mathbf{n}=15)\end{array}$ & $\begin{array}{c}\text { Saline/Lip } \\
(\mathbf{n}=15)\end{array}$ & $\begin{array}{c}\text { Formalin/Lip } \\
(\mathbf{n}=15)\end{array}$ & $\begin{array}{c}\text { Saline/TMJ } \\
(\mathbf{n}=15)\end{array}$ & $\begin{array}{c}\text { Formalin/TMJ } \\
(\mathbf{n}=12)\end{array}$ \\
\hline$\% \mathrm{TSOA}$ & $8.22 \pm 2.69^{\mathrm{b}}$ & $8.01 \pm 1.70^{\mathrm{b}}$ & $1.46 \pm 0.68^{\mathrm{a}}$ & $4.16 \pm 1.36^{\mathrm{b}}$ & $1.05 \pm 0.48^{\mathrm{a}}$ \\
$\% \mathrm{EOA}$ & $21.25 \pm 5.44^{\mathrm{b}}$ & $23.51 \pm 4.01^{\mathrm{b}}$ & $7.77 \pm 3.13^{\mathrm{a}}$ & $9.01 \pm 3.07^{\mathrm{b}}$ & $9.02 \pm 4.03^{\mathrm{a}}$ \\
NECA & $6.07 \pm 0.84^{\mathrm{b}}$ & $5.53 \pm 0.84^{\mathrm{b}}$ & $4.53 \pm 0.75^{\mathrm{b}}$ & $5.53 \pm 0.71^{\mathrm{b}}$ & $4.17 \pm 0.65^{\mathrm{b}}$ \\
\hline
\end{tabular}

${ }^{*} P<0.05$, means followed by different letters differ significantly.

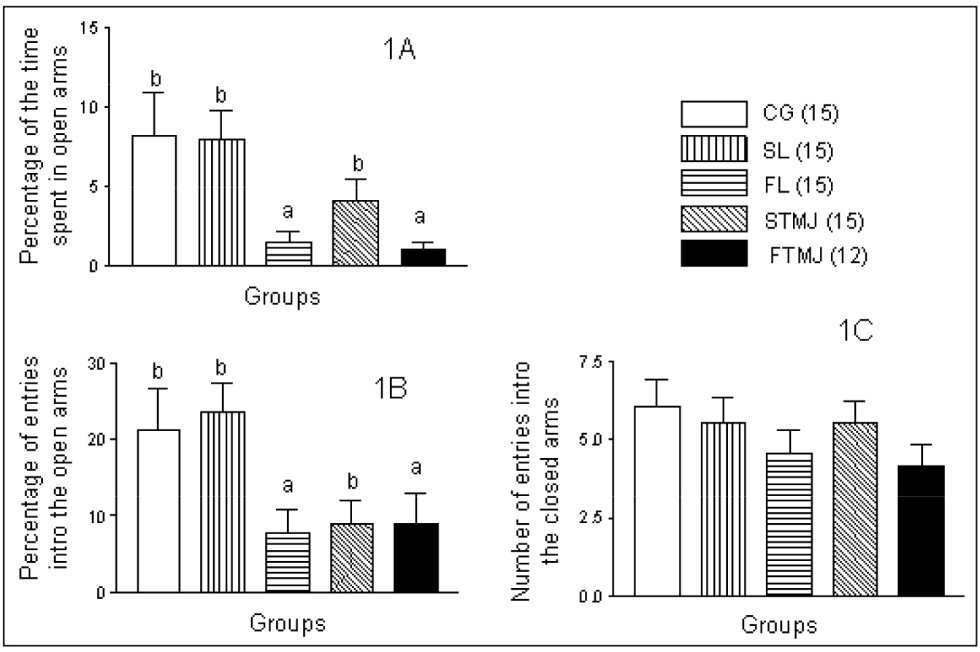

Fig. 1. Mean ( \pm S.E.M.) \%TSOA (A), \%EOA (B) and NEBF (C) of the control group (CG), saline lip (SL), formaline lip (FL), saline TMJ (STMJ and formaline TMJ (FTMJ) during the EPM test $(P<0.05)$. Sample size is indicated in parenthesis. 
Table 4. Comparison of \% TSOA, \%EOA and NECA between control and experimental groups submitted to EPM test after injection of $1 \%$ formalin in the orofacial area. Mean ( \pm standard error of the mean).

\begin{tabular}{lcccccc}
\hline & $\begin{array}{c}\text { Control group } \\
(\mathbf{n}=15)\end{array}$ & $\begin{array}{c}\text { Formalin/Lip } \\
(\mathbf{n}=15)\end{array}$ & $\begin{array}{c}\text { Formalin/Lip/ } \\
\text { Propylene }(\mathbf{n}=12)\end{array}$ & $\begin{array}{c}\text { Formalin/Lip/ } \\
\text { Diazepan }(\mathbf{n}=15)\end{array}$ & $\begin{array}{c}\text { Formalin/TMJ } \\
(\mathbf{n}=12)\end{array}$ & $\begin{array}{c}\text { Formalin/TMJ/ } \\
\text { Diazepan }(\mathbf{n}=11)\end{array}$ \\
\hline$\%$ TSOA & $8.22 \pm 2.69 \mathrm{~b}$ & $1.46 \pm 0.68^{a}$ & $0.83 \pm 0.44^{a}$ & $4.11 \pm 1.68 \mathrm{bc}$ & $1.04 \pm 0.47^{a}$ & $2.66 \pm 1.23 \mathrm{bc}$ \\
$\%$ EOA & $21.25 \pm 5.43$ & $7.76 \pm 3.13$ & $5.83 \pm 2.94$ & $15.69 \pm 5.95$ & $9.01 \pm 4.02$ & $7.90 \pm 3.35$ \\
NECA & $6.06 \pm 0.83$ & $4.53 \pm 0.74$ & $4.91 \pm 0.77$ & $3.4 \pm 0.55$ & $4.16 \pm 0.64$ & $5.36 \pm 0.946$ \\
\hline
\end{tabular}

${ }^{*} P<0.05$, means followed by different letters differ significantly.

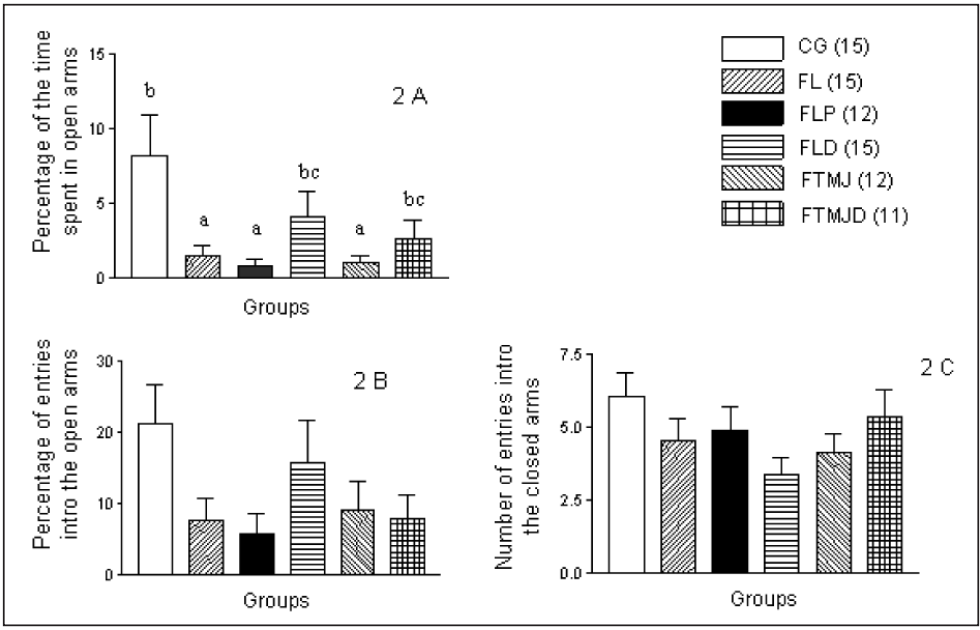

Fig. 2. Mean ( \pm S.E.M.) \%TSOA (A), \%EOA (B) and $\operatorname{NEBF}(C)$ of the control group (CG), formaline/lip (FL), formaline/lip/propylene (FLP), formaline/lip/Diazepam (FLD), formaline/TMJ (FTMJ) and formaline/TMJ/Diazepam (FTMJD) during the EPM test $(P<0.05)$. Sample size is indicated in parenthesis.
As estimated by NECA, formalin did not alter the locomotor activity of animals tested with the LCE in comparison with the rats treated with saline control (Fig. 1).

The intraperitoneal administration of Diazepam ${ }^{\circledR}(1.0 \mathrm{mg} /$ $\mathrm{kg}$ body weight) significantly reduced $(P<0.05)$ the anxietyinduced nociception response by formalin $1 \%$ injection in both lip and TMJ, as seen mainly by \%TSOA (Fig. 2 B). However, there was not effect on the locomotor activity as measured by $\%$ EOA $\%$ and NECA (Table 4 and Fig. 2).

\section{Discussion}

Orofacial pain and anxiety seem to be related (17). As the measurement of pain and anxiety in human beings is complex, animal models are useful to allow a better control of the experimental variables. The pain, similarly to different aversive stimuli, is able to alter the anxiety level of animals (15). To study orofacial pain in deep tissue many substances has been used such as mustard oil, glutamate, carrageenin and formaline (18). The FT is a reliable method for assessing pain in the trigeminal region $(10,11,15)$.

The EPM-test is an experimental model in laboratory animals to measure anxiety levels (12), where the percentage of time spent in the open arms is inversely related to anxiety levels $(12,13)$. Since the measurement of anxiety may be influenced by locomotor activity, this factor was assessed by recording the absolute number of closed-arm entries, which is considered to be an indicator of general motor activity (12). The lower percentage of time spent in the open arms by the animals that received formalin injection in the lip or in the
TMJ regions compared with the control indicated that pain increased the level of anxiety. These findings suggest that the anxiogenic effect, after formalin injections, was related with the stimulated anxiety and not to the locomotor activity of the rats.

For pain induction by injecting algesic agents in the rats' periarticular regions, the animals were first anesthetized by halothane inhalation. Although pre-administration of halothane can reduce the paw edema induced by formalin injection to a limited extent, it does not produce an inhibitory effect on the nociceptive behavioral response shown by the rats that were submitted to the formalin test (14). This ensured that there was no interference of halothane in the induction of formalin nociceptive stimuli.

Whereas there was the deposition of a certain volume of solution in the area injected (lip or TMJ), the pressure caused by this volume may have been an important factor in the activation of local nociceptors response, likely to cause pain and alter the anxiety level. However, there was no statistically significant difference neither in the percentage of time spent inside or the number of entries in the open arms, or even in the number of entries in the closed arms of the control group (GC) compared with the group that received saline injection in the lip or TMJ area. Therefore, these findings suggest that the saline injection in the orofacial region did not change the anxiety level nor the locomotor activity of rats tested with the EPM.

A reduction in the percentage of time spent inside and in the number of entries in the open arms in the EPM test induced by formalin injection in the lip and in the TMJ areas, 
compared with their controls, indicates that this procedure has an anxiogenic effect. When analyzing the number of entries in the closed arms, there was no significant difference between the groups, indicating that although the pain induced by formalin injection increases the anxiety levels, this procedure does not change the locomotor activity of the animals as previously reported by Roveroni et al. (11).

Although there are differences between the pain from superficial and deep orofacial tissues (20), which could reflect changes in the anxiety levels, the results of the present study showed that when the lip/formalin and TMJ/formalin groups were compared, the percentage of time spent in the open arms was not different between groups. This finding suggests that the injection of $1 \%$ formalin in the orofacial region produces a nociceptive stimulus that induces anxiety in a similar degree, regardless of the area in which it was injected. Probably, the mechanism of action by which formalin is able to alter the levels of anxiety involves the release of endogenous serotonin, which occurred during the phase 2 of the formalin test (20).

The increase of time spent inside the open arms by the animals that had received formalin injection in the lip or the TMJ regions associated with an application of Diazepam ${ }^{\circledR}$ injection afterwards (Table 4) shows that the intraperitoneal anxiolytic administration reduced the anxiety level caused by the formalin injections in both areas, compared with their respective controls. This demonstrated that the behavioral changes as observed during the EPM tests are related to the alterations of anxiety levels as a result of the formalin treatment. The fact that Diazepam ${ }^{\circledR}$ reduced the anxiety induced by the formalin injection in the orofacial region does not exclude the possibility that the anxiolytic could be acting directly on the nociceptive system, which would result in a change in the EPM test results. No other studies have assessed the antinociceptive effect of Diazepam ${ }^{\circledR}$ in the formalin test in the orofacial region.

Based on these results, one accepts the hypothesis that nociceptive response in rats' orofacial area induced by $1 \%$ formalin injection in the lip or the TMJ regions can influence anxiety levels. Although our results show that the formalin nociception-induced in the orofacial region can increase anxiety levels in this animal model, it is not possible to conclude that anxiety could interfere with nociception. We believe that due to the fact that there are several nerve pathways involved in both pain and anxiety, these two factors can overlap and mask the results.

Animal models allow the investigation of nociception but not of pain perception. Although the most important point to be examined is the perception of pain, it depends on a number of emotional, cultural and social factors with individual responses. This is why studies in humans are the ultimate standard to unravel the complex relationship between orofacial pain and anxiety.

Considering the relation between psychological factors and the incidence of temporomandibular disorders, anxiety is the major factor of pain perception, and individuals that show high anxiety levels in their daily behavior are more reactive to pain than those who are less anxious (21). However, the results of the present study showed that pain can also increase anxiety levels. Therefore, it is necessary that dentists acknowledge that orofacial pain, regardless of its origin, can alter patients' levels of anxiety, consequently intensifying the distress and inducing a vicious cycle in which pain and anxiety are exacerbated, which may influence the outcome of any dental treatment. This ratifies the need for the interdisciplinary approach of a health team to treat orofacial pain cases.

\section{Conclusions}

The results suggest that orofacial nociceptive response induced by $1 \%$ formaline injection in superficial (lip) and deep (TMJ) region of rats increases the anxiety level without interfering in the locomotor activity. Diazepam ${ }^{\circledR}$ reduces the anxiety caused by orofacial pain in both superficial and deep tissue.

\section{References}

1. Arntz A, Hildebrand M, Van Den Hout M. Overprediction of anxiety, and disconfirmatory processes, in anxiety disorders. Behav Res Ther 1994 Sep;32:709-22.

2. Gatchel, RJ. Managing anxiety and pain during dental treatment. J Am Dent Assoc 1992;123:37-41.

3. Alder ME, Dove SB, Murrah VA, Salinas F, Williams RF. Magnetic resonance spectroscopy of inflammation associated with the temporomandibular joint. Oral Surg Oral Med Oral Pathol 1992; 74: 515-23

4. Swift JQ, Roszkowski MT, Alton T, Hargreaves KM. Effect of intraarticular versus systemic anti-inflammatory drugs in a rabbit model of temporomandibular joint inflammation. J Oral Maxillofac Surg 1998;56: 1288-95.

5. Pratt JA. The neuroanatomical basis of anxiety. Pharmacol Ther $1992 ; 55: 149-81$
6. Malmberg AB, Yaksh, TL. Antinociceptive actions of spinal nonsteroidal anti-inflammatory agents on the formalin test in the rat. J Pharmacol Exp Ther 1992;263:136-46.

7. Dubuisson, D, Dennis, SG. The formalin test: a quantitative study of the analgesic effects of morphine, meperidine and brain stem stimulation in rats and cats. Pain 1977;4:161-74.

8. Wheeler-Aceto H, Cowan A. Naloxone causes apparent antinociception and pronociception simultaneously in the rat paw formalin test. Eur J Pharmacol 1993;236:193-9.

9. Lee I, Crosby G. Halothane effect on formalin-induced paw edema and flinching in rat. J Korean Med Sci 1999;14: 34-8.

10. Clavelou P, Dallel R, Orliaguet T, Woda A, Raboisson P. The orofacial formalin test in rats: effects of different formalin concentrations. Pain 1995;62:295-301. 
11. Roveroni RC, Parada CA, Veiga MCFA, Tambeli CH. Development of a behavioral model of TMJ pain in rats: the TMJ formalin test. Pain 2001;94:185-91.

12. Pellow S, Chopin P, File SE, Briley M. Validation of open-closed arm entries in an elevated plus-maze as a measure of anxiety in the rats. J Neurosci Methods 1985;14:149-67.

13. Cruz AP, Frei F, Graeff FG. Ethopharmacological analysis of rat behavior on the elevated plus-maze. Pharmacol Biochem Behav 1994;49:171-6.

14. Montgomery KC. The relation between fear induced by novel stimulation and exploratory behavior. J Comp Physiol Psychol 1955;48:254-60.

15. McBlane JW, Handley SL. Effects of two stressors on behaviour in the elevated X-maze: preliminary investigation of their interaction with 8-OH-DPAT. Psychopharmacology (Berl) 1994; 1 16:173-82.

16. Fernández-Guasti A, Picazo $O$. The actions of diazepam and serotonergic anxiolytics vary according to the gender and the estrous cycle phase. Pharmacol Biochem Behav 1990; 37:77-81.

17. de Castro AR, de Siqueira SR, Perissinotti DM, de Siqueira JT. Psychological evaluation and cope with trigeminal neuralgia and temporomandibular disorder. Arq Neuropsiquiatr 2008;66: 716-9.

18. Boleta-Ceranto DCF, Veiga MCFA, Arsati F. Efeito da dexametasona e do meloxicam sobre o extravasamento plasmático induzido por carragenina na ATM de ratos. Rev Odonto Ciênc 2005;20: 354-60.

19. Clavelou P, Pajot J, Dallel R, Raboisson P. Application of the formalin test to the study of orofacial pain in the rat. Neurosci Lett 1989;103:349-53.

20. Hu JW. Deep craniofacial pain: involvement of trigeminal subnucleus caudalis and its modulation. In: Jensen TS, Turner JA, WiesenfeldHallin Z. (Ed.) Proceedings of the $8^{\text {th }}$ World Congress on Pain: progress in pain research and management. Seattle: IASP Press; 1997.

21. Pereira LJ, Pereira-CenciT, Pereira SM, Cury AADB, Ambrosano BMB; Pereira AC, Gavião MBDG. Psychological factors and the incidence of temporomandibular disorders in early adolescence. Braz Oral Res 2009;23:155-60.

22. Wepman BJ. Psychological components of pain perception. Dent Clin North Am 1978;22:101-13. 